\title{
KETERLIBATAN PARA AKTOR \\ DALAM PENGENDALIAN KONVERSI LAHAN PERTANIAN (STUDI KASUS DI KABUPATEN TABANAN, PROVINSI BALI)
}

\author{
Involvement of The Actors in Conversion Control of Agricultural Land \\ (Case Study in Tabanan District, Bali Province)
}

\author{
Widhianthini ${ }^{1}$, Arya Hadi Dharmawan ${ }^{2}$, Noer Azam Achsani ${ }^{3}$, dan Setia Hadi ${ }^{4}$ \\ ${ }^{1}$ Departemen Agribisnis, Fakultas Pertanian, Universitas Udayana, Denpasar Bali \\ ${ }^{2}$ Departemen Sosiologi Pedesaan, Fakultas Ekologi Manusia, IPB \\ ${ }^{3}$ Departemen Ilmu Ekonomi, Fakultas Ekonomi dan Manajemen, IPB \\ ${ }^{4}$ Departemen Arsitektur Landskap, Fakultas Pertanian, IPB \\ *) E-mail: wiwin_purantara@yahoo.com
}

\begin{abstract}
The purpose of this research is to know how the role of government actors, private or investors and indigenous institutions (Subak and Pakraman) in the management of land resources (including water) so that the conversion of agricultural land can be prevented. The study was conducted in Tabanan, Bali Province. Depth interview techniques and stakeholder analysis as an approach of this research. A stakeholder analysis is instrumental to understand the social and institutional context of a program or project activities. The purpose of stakeholder analysis is to determine interests and their authority in preventing the conversion of agricultural land. The results showed that there are two forces actors (stakeholders) in the management of land resources (including water). The government in collaboration with investors and has a role as a player, while Subak and Pakraman have a role on the position of the object. Power relations are played by actors of government is still dominant compared to indigenous institutional Subak and Pakraman. Investors who have the capital strength and enthroned as the 'king' always pave the spatial plannings are on 'profit-seeking' biggest for himself. Power is seen as a mechanism of domination which is a form of power against the other in a relationship dominated by dominated or powerfull by the powerless. The duality of land governance (including water) between actors is the dualism solution. The duality that lies in the fact, that he could be seen as rules that a principle for action in a wide range of space and time, while it is the result (outcome) and means looping action thus overcoming space and time. Duality of land governance (including water) shows that in the future that is necessary is to put Subak and Pakraman in a position of political strength parallel to desa dinas and other government institutions.
\end{abstract}

Keywords: indigenous institutions (Subak, Pakraman), conversion of agricultural land, stakeholder analysis, duality ofland governance

\begin{abstract}
ABSTRAK
Tujuan dari penelitian ini adalah mengetahui bagaimana peran aktor pemerintah, swasta atau investor, dan kelembagaan lokal (subak dan desa pakraman) dalam pengelolaan sumber daya lahan (termasuk air) sehingga konversi lahan pertanian dapat dicegah. Penelitian dilakukan di Kabupaten Tabanan, Propinsi Bali. Teknik wawancara yang mendalam dan analisis stakeholder sebagai pendekatan penelitian ini. Analisis stakeholder merupakan instrument untuk memahami konteks social dan kelembagaan dari program atau kegiatan proyek. Tujuan dari analisis stakeholder adalah untuk menentukan minat dan kewenangan mereka dalam mencegah konversi lahan pertanian. Hasil memperlihatkan bahwa terdapat dua kekuatan aktor (stakeholder) dalam pengelolaan sumberdaya lahan (termasuk air). Pemerintah berkolaborasi dengan investor dan memiliki peran sebagai pemain, sedangkan subak dan desa pakraman memiliki peran pada posisi objek. Relasi kuasa yang dimainkan oleh aktor pemerintah masih bersifat dominan dibandingkan kelembagaan lokal subak dan desa pakraman. Aktor investor yang memiliki kekuatan modal dan bertahta sebagai 'raja' selalu melicinkan perencanaanperencanaan tata ruang yang memberikan 'profit seeking' terbesar bagi dirinya. Kekuasaan dipandang sebagai mekanisme dominasi yang merupakan bentuk kekuasaan terhadap yang lain dalam relasi yang mendominasi dengan yang didominasi atau yang berkuasa dengan yang tidak berdaya. Dualitas tata kelola lahan (termasuk air) antar para aktor merupakan pemecahan dualism tersebut. Dualitas itu terletak dalam fakta, bahwa ia bisa dipandang sebagai aturan yang menjadi prinsip bagi tindakan di berbagai ruang dan waktu, sekaligus ia merupakan hasil (outcome) dan sarana perulangan tindakan yang karenanya mengatasi ruang dan waktu. Dualitas tata kelola lahan (termasuk air) ini menunjukkan bahwa kedepan yang diperlukan adalah menempatkan subak dan desa pakraman pada posisi kekuatan politik yang sejajar dengan desa dinas dan kelembagaan pemerintah lainnya.
\end{abstract}

Kata kunci: kelembagaan lokal (subak, desa pakraman), konversi lahan pertanian, analisis stakeholder, dualitas tata kelola lahan

\section{PENDAHULUAN}

Tata kelola sumberdaya alam saat ini mengarah pada rujukan pembangunanisme dan neoliberalisme. Kedua rujukan ini berakar pada fisik dan ekonomi (pengejaran keuntunga, rent seeking). Peran pemerintah yang berkolaborasi dengan pihak swasta (investor) sering mendominasi kebijakan-kebijakan yang terkait dengan pengelolaan sumberdaya alam. Kedua aktor tersebut memunculkan perilaku eksplorasi dan eksploitatif, 
terlebih-lebih terhadap sumberdaya yang diklaim milik negara.

Kondisi ini berbeda halnya dengan pihak subordinat, masyarakat lokal atau yang terbentuk dalam suatu kelembagaan lokal. Kelembagaan lokal yang sering merupakan aktor inferior tidak dapat mendeklarasikan keinginannya untuk menyelamatkan sumberdaya alam di sekitarnya akibat lemahnya "payung pengaman" dalam bentuk regulasi.

Esensi sumberdaya alam sebagai komoditas ekonomi sering berdampak negatif bagi kelembagaan lokal, seperti terjadinya konversi lahan pertanian. Penyebab pertama, kebijakan yang kontradiktif terjadi karena di satu pihak pemerintah berupaya melarang terjadinya alih fungsi, tetapi di sisi lain kebijakan pertumbuhan industri/manufaktur dan sektor non pertanian lainnya justru mendorong terjadinya alih fungsi lahan-lahan pertanian. Penyebab kedua, cakupan kebijakan yang terbatas. Peraturan-peraturan tersebut di atas baru dikenakan terhadap perusahaan-perusahaan/badan hukum yang akan menggunakan tanah dan/atau akan merubah tanah pertanian ke non pertanian (Newburn 2006). Perubahan penggunaan tanah sawah ke non pertanian yang dilakukan secara individual/peorangan belum tersentuh oleh peraturan-peraturan tersebut. Padahal perubahan fungsi lahan yang dilakukan secara individual secara langsung diperkirakan cukup luas. Dalam kenyataannya, RTRW justru merencanakan untuk mengkonversi tanah sawah beririgasi teknis menjadi nonpertanian.

Kelemahan lain dalam peraturan perundangan yang ada yaitu: (i) Objek lahan pertanian yang dilindungi dari proses konversi ditetapkan berdasarkan kondisi fisik lahan, padahal kondisi fisik lahan relatif mudah direkayasa, sehingga konversi lahan dapat berlangsung tanpa melanggar peraturan yang berlaku; (ii) Peraturan yang ada cenderung bersifat himbauan dan tidak dilengkapi sanksi yang jelas, baik besarnya sanksi maupun penentuan pihak yang dikenai sanksi; (iii) Jika terjadi konversi lahan pertanian yang tidak sesuai dengan peraturan yang berlaku sulit ditelusuri lembaga yang paling bertanggung jawab untuk menindak karena ijin konversi adalah keputusan kolektif berbagai instansi (Pasandaran 2006).

Phuc et al. (2014) dalam penelitiannya mengatakan bahwa integrasi progresifVietnam ke dalam ekonomi pasar global telah memicu transformasi ekonomi dan sosial yang besar. Dalam kaitannya dengan tata ruang ditandai dengan konversi lahan pertanian secara besar-besaran untuk pengembangan industri dan perkotaan. Kondisi ini meningkatkan ketegangan rasial dan keluhan dari masyarakat yang terkena dampak. Negara menggunakan kekuasaan yang luas dalam proses pengambilan keputusan sementara partisipasi dari masyarakat yang terkena dampak adalah pasif dan lemah. Konversi lahan yang terjadi merupakan hasil dari "mencari keuntungan" (profit-seeking) oleh berbagai pengambil kebijakan (stakeholders).

Kasus yang terjadi di Cina, sebagian besar perluasan urbanisasi pada tahun-tahun belakangan ini dilakukan melalui konversi lahan perdesaan. Besaran lahan pertanian yang kini tersedia mendekati "batas garis merah" 120 juta hektar, yang dianggap sebagai besaran minimum dalam memastikan ketahanan pangan (Li Yuheng et al. 2015). Nurliana dan Ida Rosida (2016) memaparkan juga bahwa konversi lahan sawah di Kabupaten Pangkep, Sulawesi Selatan terjadi karena produktivitas yang lebih rendah dari sawah, rendahnya kualitas tanah, dan nilainilai ekonomi yang lebih tinggi dari tanah milik pesaing. Kondisi tersebut terjadi secara kumulatif, secara permanen, dan progresif. Penelitian yang dilakukan oleh Sihaloho et al. (2007) memaparkan bahwa konversi lahan pertanian berimplikasi pada perubahan struktur agraria. Perubahan ini akan menghasilkan ketimpangan struktur agraria lahan terhadap kehidupan masyarakat. Perbuahan tersebut meliputi perubahan pola penguasaan lahan, pola nafkah, dan hubungan pola produksi.

Berkembangnya industri pariwisata, seperti maraknya villa, cottage, atau hotel telah mengubah struktur agraria dalam konteks penguasaan tanah dari makna tanah yang bersifat kolektif dalam organisasi produksi agraria subak menjadi makna tanah yang bersifat privat individualistik, manakala tanahtanah berubah peruntukannya menjadi hotel yang komersial. Kondisi ini mempengaruhi keberadaan subak yang basis filosofi agrarianya "kolektivitas" dalam pendistribusian air berubah menjadi disfungsional karena struktur agrarianya menjadi privat individualistik. Ketidakberfungsian subak melalui "proses individualisasi penguasaan tanah" menyebabkan laju konversi lahan pertanian dari peruntukan pangan ke non pangan (turisme) meluncur dengan hebat.

Berkembangnya berbagai industri pariwisata massal tersebut diperkuat dengan kewenangan para penguasa. Barker (2011) memaparkan bahwa penguasa merupakan blok historis yang menjalankan otoritasnya kepada kaum petani. Kebijakankebijakan yang diambil pemerintah dengan alasan telah disetujui melalui sebuah konsensus dimana telah terselip kesepakatan yang merugikan petani.

Subak dan desa pakraman di Bali merupakan salah satu contoh aktor di tingkat masyarakat lokal yang memiliki posisi yang tidak sejajar dengan aktor dari pihak pemerintah. Keberadaan kelembagaan lokal subak dan desa pakraman membutuhkan legitimasi dalam menjalankan perannya. Penelitian ini difokuskan pada peran para aktor di tingkat pemerintah dan aktor di tingkat kelembagaan lokal subak dan desa pakraman dalam mencegah atau mengendalikan konversi lahan pertanian, yang nantinya akan berdampak pada pengelolaan sumberdaya air.

\section{METODE PENELITIAN}

\section{Lokasi dan Pengambilan Sampel}

Penelitian ini dilakukan selama enam bulan (Agustus 2013-Januari 2014) di Kabupaten Tabanan, Propinsi Bali. Pemilihan lokasi di Kabupaten Tabanan didasarkan karena kabupaten ini merupakan lumbung padi di Propinsi Bali dimana 70 persen kawasannya merupakan kawasan perdesaan telah mengalami alih fungsi lahan pertanian (sawah). Pengambilan sampel secara purposive sampling. Sampel ditujukan pada aktor yang berperan dalam pengelolaan lahan (stakeholder di tingkat pemerintah, yaitu Bappeda Kabupaten Tabanan, dinas pertanian, dinas pekerjaan umum sub irigasi kabupaten, dinas pariwisata kabupaten, dinas pendapatan daerah kabupaten, desa dinas), investor, dan aktor di tingkat subak dan desa pakraman.

\section{Pendekatan Metode}

Peran aktor di tingkat pemerintahan dan kelembagaan lokal/adat dalam mengantisipasi konversi lahan pertanian dapat dikaji melalui analisis stakeholders. Bryson (2003) memaparkan bahwa analisis stakeholders ini merupakan instrumen yang sangat penting untuk memahami konteks sosial dan kelembagaan dari satu kegiatan program atau proyek. Tujuan analisis stakeholders adalah untuk mengetahui 


\section{Tinggi}

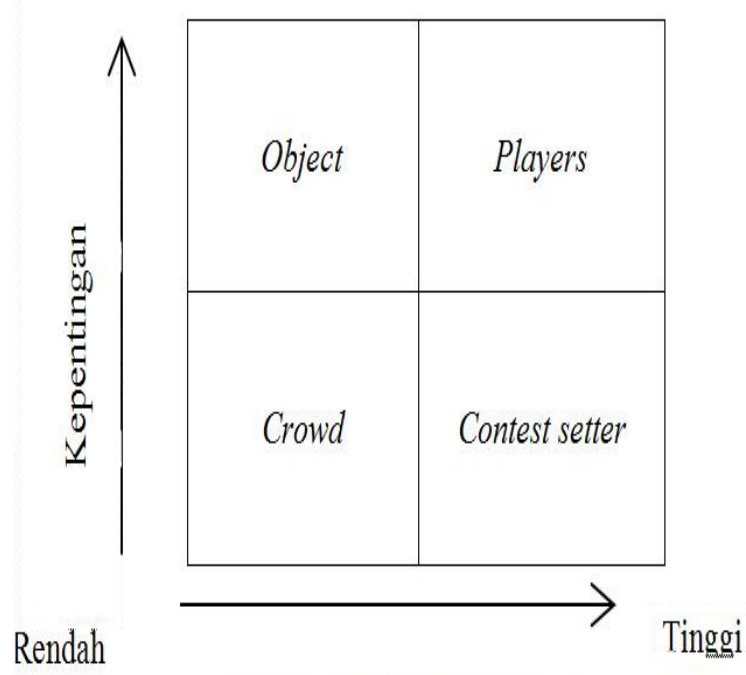

Kekuatan

Gambar 1. Matriks Analisis Stakeholders

minat/kepentingan dan peranan masing-masing stakeholders dan wewenang mereka dalam penataan kawasan desa wisata berkelanjutan. Keberhasilan dari penanganan suatu masalah yang rumit dan terkait dengan banyak pihak, bergantung pada pemahaman yang jelas pada minat dan hubungan antar stakeholders.

Analisis ini dimulai dengan menyusun stakeholders pada matriks dua kali dua menurut interest (minat) stakeholders terhadap suatu masalah dan power (kewenangan) stakeholders dalam mempengaruhi masalah tersebut. Minat adalah kepentingan stakeholders terhadap penataan kawasan desa wisata berkelanjutan. Hal ini bisa dilihat dari tugas pokok dan fungsi (tupoksi) masing-masing stakeholders. Sedangkan yang dimaksud dengan power/kewenangan adalah kekuasaan stakeholders untuk mempengaruhi atau membuat kebijakan maupun peraturan-peraturan yang berkaitan dengan pengelolaan lahan. Analisis stakeholders ini dikelompokkan dalam empat kuadran. Empat kuadran tersebut yaitu: object, players, crowd, dan contest setter (Bryson 2003).

Object adalah mereka yang mempunyai minat besar namun wewenangnya kecil terhadap perencanaan, pengawasan, dan evaluasi terhadap pengelolaan lahan di suatu wilayah. Players adalah mereka yang mempunyai minat besar dan wewenang yang besar. Players dapat diartikan sebagai pemain/pelaksana pengelolaan lahan mulai dari perencanaan hingga evaluasi. Mereka dapat bekerja optimal karena selain minat atau tupoksinya terkait langsung dengan pengelolaan lahan, mereka juga mempunyai wewenang untuk melakukan sesuatu atau membuat aturan yang terkait dengan konversi lahan. Contest setter adalah mereka yang mempunyai minat kecil dan wewenang yang besar. Contest setter merupakan perencana makro dari pembangunan, dimana lingkup kerjanya sangat luas. Posisi ini menyebabkan minat mereka kecil terhadap pengelolaan lahan. Wewenang besar terjadi karena contest setter mempunyai wewenang untuk mengesahkan program-program dari instansi terkait. Crowd adalah mereka yang mempunyai minat kecil dan wewenang yang kecil dalam pengelolaan lahan.

Pengkajian kedudukan melalui analisis stakeholders akan memperlihatkan posisi kelembagaan lokal/adat yang sebenarnya di lapangan. Pengkajian berikutnya adalah melakukan analisis deskriptif untuk mengkaji upaya-upaya yang sebaiknya dilakukan kelembagaan lokal/adat dalam mengurangi atau menekan konversi lahan pertanian sehingga posisi yang diharapkan berada di tingkat pemain (players).

\section{HASIL DAN PEMBAHASAN}

\section{Peran Stakeholders dalam Mencegah Konversi Lahan Pertanian}

Peran para stakeholders di Kabupaten Tabanan dalam pengelolaan ruang khususnya mencegah alih fungsi lahan dan menuju pengembangan desa wisata berkelanjutan, ternyata tidak sama. Meskipun dinas pertanian dalam tugasnya memiliki peranan dalam mengembangkan, merehabilitasi, mengkonservasi, mengoptimalkan dan mengendalikan lahan pertanian dan air serta sumber daya hayati serta ekosistemnya di wilayah kabupaten, dalam pelaksanaannya lebih banyak terfokus pada kegiatan pelaksanaan budidaya pertanian.

Berbeda halnya dengan Dinas Pekerjaan Umum (PU) bidang pengairan, peranan yang dilakukan meliputi: melaksanakan kegiatan perencanaan teknis program kerja di bidang pengairan; melaksanakan kegiatan pembangunan, pemeliharaan, pengawasan serta monitoring/evaluasi kegiatan di bidang pengairan; melaksanakan kegiatan pembangunan, pemeliharaan, pengawasan serta monitoring/evaluasi kegiatan prasarana sungai dan rawa; dan melaksanakan kegiatan pembangunan, pemeliharaan, pengawasan serta monitoring/ evaluasi kegiatan prasarana danau dan pantai. Keterlibatannya sudah mengarah dari perencanaan hingga evaluasi kegiatan. Dalam kaitannya dengan pelaksanaan program pengembangan desa wisata berkelanjutan, Dinas Pekerjaan Umum bidang tata ruang memiliki keterlibatan dalam penyusunan Rencana Detail Tata Ruang (RDTR) dan zoning regulatian (peraturan zona).

Tabel 1. Peran Stakeholders dalam Pengendalian Konversi Lahan yang Berbasis Kelembagaan Lokal

\begin{tabular}{|c|c|c|}
\hline Stakeholders & $\begin{array}{l}\text { Peranan dalam } \\
\text { Penataan Ruang }\end{array}$ & $\begin{array}{c}\text { Ruang } \\
\text { Lingkup }\end{array}$ \\
\hline $\begin{array}{l}\text { Bappeda } \\
\text { Kabupaten }\end{array}$ & $\begin{array}{l}\text { Perencanaan, } \\
\text { Pelaksanaan, } \\
\text { Monitoring }\end{array}$ & Kabupaten \\
\hline $\begin{array}{l}\text { Dinas Pertanian } \\
\text { Kabupaten }\end{array}$ & $\begin{array}{l}\text { Perencanaan, } \\
\text { Pelaksanaan, } \\
\text { Monitorfing }\end{array}$ & $\begin{array}{l}\text { Kabupaten, } \\
\text { Subak }\end{array}$ \\
\hline $\begin{array}{l}\text { Dinas Pariwisata } \\
\text { Kabupaten }\end{array}$ & $\begin{array}{l}\text { Perencanaan, } \\
\text { Pelaksanaan, } \\
\text { Monitoring }\end{array}$ & $\begin{array}{l}\text { Kabupaten } \\
\text { dan Desa }\end{array}$ \\
\hline $\begin{array}{l}\text { Dinas PU (Irigasi } \\
\text { dan Tata Ruang) } \\
\text { Kabupaten }\end{array}$ & $\begin{array}{l}\text { Perencanaan, } \\
\text { Pelaksanaan, } \\
\text { Monitoring }\end{array}$ & $\begin{array}{l}\text { Kabupaten, } \\
\text { Desa dan } \\
\text { Subak }\end{array}$ \\
\hline Dispenda & $\begin{array}{l}\text { Perencanaan, } \\
\text { Pelaksanaan, } \\
\text { Monitoring }\end{array}$ & $\begin{array}{l}\text { Kabupaten, } \\
\text { Subak }\end{array}$ \\
\hline Investor & $\begin{array}{l}\text { Perencanaan, } \\
\text { pelaksanaan }\end{array}$ & $\begin{array}{l}\text { Kabupaten, } \\
\text { desa, subak }\end{array}$ \\
\hline Subak & Pelaksanaan & Subak \\
\hline Desa Pakraman & Pelaksanaan & $\begin{array}{l}\text { Desa Adat dan } \\
\text { Subak }\end{array}$ \\
\hline Desa Dinas & Pelaksanaan & Desa \\
\hline
\end{tabular}


Tupoksi yang dijalankan oleh dinas ini hampir menyerupai tupoksi yang dilakukan di tingkat Bappeda kabupaten bidang tata ruang dan lingkungan hidup.

Tupoksi yang dilakukan pihak Bappeda kabupaten lebih luas wewenangnya dibandingkan yang dilakukan oleh dinas. Kegiatan yang dilakukannya meliputi: pengkajian kebijakan dan peraturan di bidang tata ruang; pelaksanaan koordinasi dan sinkronisasi perencanaan pembangunan kabupaten di bidang tata ruang; penyusunan rencana pembangunan kabupaten di bidang tata ruang; penyusunan rencana pendanaan pembangunan di bidang tata ruang; pelaksanaan inventarisasi dan analisis berbagai kebijakan dan informasi yang berkaitan dengan penyiapan rencana pendanaan pembangunan di bidang tata ruang; pemantauan, evaluasi, penilaian, dan pelaporan atas pelaksanaan rencana, kebijakan, dan program-program pembangunan di bidang tata ruang. Terkait dengan pencegahan konversi lahan atau penyelamatan jalur hijau, pihak Dinas Pendapatan Daerah (Dispenda) menetapkan sistem pajak lahan berdasarkan sistemik. Sistemik ini berdasarkan peta, tidak berdasarkan sumber air (sistem sebelumnya). Sistem ini didasarkan atas aksesibilitas lahan. Semakin dekat dengan akses jalan besar maka semakin mahal pajak yang ditetapkan dan sebaliknya. Dispenda juga melakukan pemantauan setiap tiga bulan sekali. Kabupaten Tabanan telah menerapkan sistem ini sejak bulan Januari tahun 2015.

Dinas pariwisata kabupaten juga terlibat dalam program pengendalian konversi lahan pertanian. Tupoksi yang dilakukan lebih mengarah pembinaan pada desa-desa wisata. Keterlibatannya tidak seperti sebelumnya. Dahulu pendanaan yang terkait untuk pengembangan desa wisata melibatkan peranan dinas pariwisata. Sejak tahun 2009, hal-hal yang terkait dengan pendanaan diserahkan langsung pengelolaannya ke desa-desa wisata.

Subak sebagai suatu masyarakat hukum adat yang memiliki karakteristik sosioagraris - religius, yang merupakan perkumpulan petani yang mengelola air irigasi hanya dilibatkan pada tahap pelaksanaan pemanfaatan ruang, seperti kasus subak di Desa Jatiluwih, Kecamatan Penebel, saat dinobatkan sebagai warisan budaya dunia (WBD). Saat perencanaan hingga saat ini subak Jatiluwih tidak dilibatkan. Kondisi ini menyebabkan masyarakat di desa Jatuluwih atas inisiatif sendiri membentuk Badan Pengelola Daya Tarik Wisata Jatiluwih (BP-DTW). Badan pengelola DTW ini berperan mengelola dana retribusi dari wisata alam subak di Desa Jatiluwih. Badan pengelola ini berdiri sejak Januari tahun 2014 dan terealisasi bulan Februari tahun 2014. Pengelola terdiri dari masyarakat yang merupakan perwakilan dari banjar, perwakilan adat, perwakilan subak, dan perwakilan desa dinas Jatiluwih.. Desa dinas lebih banyak menangani hal-hal administrasi dan juga sebagai pengevaluasi dari program-program pembangunan di desa. Kondisi ini memperlihatkan bahwa antara subak, desa adat, dan desa dinas di Desa Jatiluwih sudah memiliki keterpaduan dan keserasian dalam setiap program.

\section{Analisis Stakeholders}

Analisis stakeholders dalam pengendalian konversi lahan pertanian diawali dengan membuat matriks dua kali dua menurut minat (interest) stakeholders terhadap masalah dan kewenangan (power) stakeholders dalam mempengaruhi masalah tersebut (Bryson 2003). Matriks analisis ini dapat dilihat pada gambar 2 .

Kedelapan stakeholders dalam pengendalian konversi lahan pertanian dikelompokkan menjadi empat kuadran sebagai berikut:

\section{A. Object}

Jika dilihat dari fungsi subak, subak merupakan kelembagaan lokal yang mengelola masalah air irigasi dan pengaturan pola tanam. Subak merupakan kelembagaan lokal yang memiliki minat besar dalam pengendalian konversi lahan pertanian. Umumnya subak menginginkan konversi lahan sawah dapat dikurangi dan bahkan tidak terjadi lagi. Kewenangan subak dalam penataan ruang

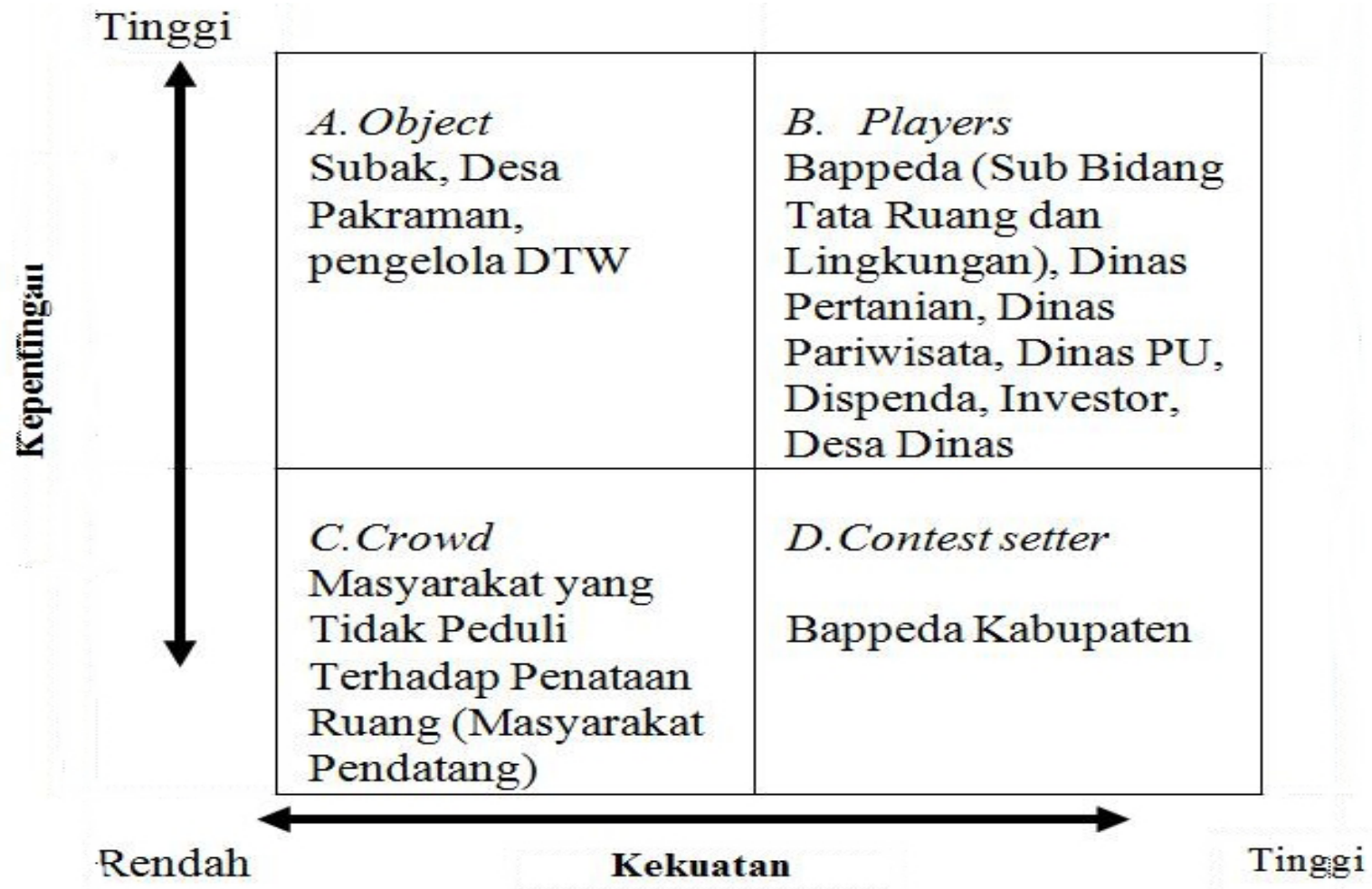

Gambar 2. Matriks analisis stakeholders dalam pengendalian konversi lahan pertanian yang berbasis kelembagaan lokal di Kabupaten Tabanan 
sangat kecil karena dalam perencanaan RTRWK Tabanan sampai evaluasi, lebih banyak didominasi oleh pihak Bappeda dan dinas terkait. Jika terjadi masalah konflik air antar subak atau antar desa maka barulah subak akan dilibatkan dalam perencanaan tata ruang, khususnya yang menyangkut masalah air irigasi

Desa pakraman (desa adat) sebagai desa dresta merupakan kesatuan masyarakat hukum adat di Provinsi Daerah Tingkat I Bali yang mempunyai satu kesatuan tradisi dan tata krama pergaulan hidup masyarakat umat Hindu secara turun temurun dalam ikatan Kahyangan Tiga (Kahyangan Desa) yang mempunyai wilayah tertentu, harta kekayaan sendiri, dan berhak mengurus rumah tangganya sendiri (Peraturan Daerah Propinsi Bali Nomor 3 Tahun 2001). Desa pakraman yang merupakan pelindung keberadaan subak juga memiliki kewenangan yang kecil dalam pengendalian konversi lahan. Kewenangannya hanya mencakup wilayah desa adat saja dan upacara keagamaan.

Kewenangan pengelola DTW sebagai mitra subak dan salah satu elemen pengembangan kawasan desa wisata, dalam penataan ruang juga sangat kecil. Walaupun keberadaan DTW memberikan kontribusi dana kepada pemda setempat, pengelola DTW yang merupakan perwakilan dari anggota subak dan krama desa adat tidak dilibatkan mulai dari perencanaan sampai evaluasi pengembangan kawasan desa wisata.

\section{B. Players}

Bappeda sub bidang tata ruang dan lingkungan hidup memiliki minat dan wewenang besar dalam penyusunan tata ruang kabupaten. Tupoksi yang dijalankan sub bidang ini diantaranya meliputi: penyusunan usulan rencana kerja, kinerja, dan anggaran tahunan seksi perencanaan penataan ruang; pemberian fasilitas, pembinaan di bidang perencanaan penataan ruang; pelaksanaan penyusunan rencana umum dan rinci tata ruang kota; penyusunan bahan peraturan zonasi (zoning map dan zoning teks) sebagai penjabaran dari rencana detail tata ruang; penyiapan bahan legislasi untuk produk rencana tata ruang; pelaksanaan fasilitasi peningkatan peran serta masyarakat dalam perencanaan tata ruang; dan pelaksanaan koordinasi serta fasilitasi penyusunan rencana tata ruang lintas kabupaten/ kota. Walaupun memiliki tupoksi sebagai fasilitator peningkatan peran serta masyarakat dalam perencanaan tata ruang, peran ini jarang melibatkan kelembagaan lokal (subak, desa pakraman, desa dinas) dari awal. Pihak Bappeda lebih bekerjasama dengan dinas-dinas terkait.

Dinas pertanian memiliki tugas dalam perencanaan pembangunan pertanian berkelanjutan. Undang-Undang Nomor 41 Tahun 2009 tentang Perlindungan Lahan Pertanian Pangan Berkelanjutan mengarahkan tupoksi dinas pertanian pada penetapan kebijakan, pedoman, dan bimbingan pengembangan, rehabilitasi, konservasi, optimasi dan pengendalian lahan pertanian tingkat kabupaten. Tupoksi lainnya yang juga dijalankan dinas pertanian adalah menetapkan sentra komoditas pertanian wilayah kabupaten, sasaran areal tanam dan luas baku lahan pertanian yang dapat diusahakan sesuai kemampuan sumberdaya lahan yang ada pada skala kabupaten. Meskipun petani subak dilibatkan dalam perencanaan waktu tanam, perencanaan secara keseluruhan masih dipegang kendalinya oleh dinas pertanian.

Dinas pariwisata kabupaten Tabanan memiliki tupoksi dalam pengendalian konversi lahan pertanian, melaksanakan pemantauan, evaluasi, pengendalian dan penertiban serta melaksanakan proses tindakan hukum terhadap pelanggaran usaha pariwisata. Dalam penyusunan perencanaan kawasan desa wisata yang berkelanjutan, dinas pariwisata melibatkan desa dinas, desa pakraman, dan subak untuk menentukan prioritas keunggulan desa. Pembinaan-pembinaan juga dilakukan oleh dinas pariwisata.

Dinas PU bagian pengairan memiliki tupoksi melaksanakan kewenangan otonomi daerah kabupaten dalam rangka pelaksanaan tugas desentralisasi di bidang pekerjaan umum pengairan. Tupoksi tersebut diantaranya: menyusun, merencanakan teknis pembangunan dan rehabilitasi, operasi dan pemeliharaan serta pemanfaatannya. Dalam bidang pembangunan dan rehabilitasi, dinas PU melaksanakan penyiapan perumusan kebijakan teknis dan strategis, koordinasi, pembinaan, pengendalian dan pemberian bimbingan teknis di bidang tersebut. Tupoksi ini juga dilakukan di bidang operasi dan pemeliharaan. Tugas perencanaan hingga evaluasi masih didominasi oleh dinas PU bagian pengairan karena menyangkut jaringan primer dan jaringan sekunder. Subak hanya dilibatkan pada perencanaan di tingkat jaringan tersier.

Dinas PU bagian tata ruang memiliki tupoksi, diantaranya: menyusun bahan peraturan zonasi (zoning map dan zoning teks) sebagai penjabaran dari rencana detail tata ruang; menyiapkan bahan legislasi untuk produk rencana tata ruang, dan melaksanakan koordinasi serta fasilitasi penyusunan rencana tata ruang lintas kabupaten/kota. Tupoksi ini dilakukan dinas PU bagian tata ruang dengan mengkoordinasikan pada Bappeda kabupaten.

Terkait dengan kawasan Warisan Budaya Dunia (WBD) Jatiluwih, keterlibatan dinas PU bagian tata ruang sangat besar. Untuk mengantisipasi perkembangan pemanfaatan ruang yang semakin pesat di Kecamatan Penebel, maka diperlukan aturan pola pemanfaatan ruang yaitu berupa pengaturan zona yang merupakan turunan atau kategori yang lebih detail dari kawasan. Semakin besar dan kompleks kawasan maka semakin beragam jenis-jenis zona yang harus diatur. Berdasarkan hal tersebut Kawasan WBD Jatiluwih, Kecamatan Penebel membutuhkan sebuah peraturan zonasi (zoning regulation) yang berfungsi sebagai instrumen pengendalian pembangunan dan panduan teknis pengembangan dan pemanfaatan lahan. Dinas PU bagian tata ruang bekerjasama dengan dinas terkait (dinas pertanian, dinas kehutanan, dinas pariwisata, Bappeda di tingkat kabupaten dan propinsi) telah menyusun Rencana Detail Tata Ruang (RDTR) kawasan Jatiluwih. Kegiatan ini bertujuan untuk menyusun Rancangan Peraturan Daerah (Ranperda) beserta materi Peraturan Zonasi Kawasan WBD Jatiluwih dengan kedalaman peta sekurangnya 1:5.000 yang dapat memenuhi kebutuhan pembangunan dan menyusun mekanisme pengendalian pemanfaatan ruang yang menyangkut aspek kelembagaan, perizinan, insentif, dan disinsentif, pengenaan sanksi hukum, dan hal-hal yang menyangkut peraturan tata ruang lainnya.

Dinas Pendapatan Daerah (Dispenda) Kabupaten Tabanan merupakan dinas yang menjalankan tupoksi dalam pemungutan pajak bumi dan bangunan serta pajak jalur hijau. Peraturan Daerah Kabupaten Tabanan (Perda) Nomor 6 Tahun 2014 menyebutkan bahwa kawasan jalur hijau merupakan suatu kawasan atau hamparan tanah yang luas yang berfungsi untuk pelestarian pertanian, perkebunan, dan penyelamatan daerah resapan air serta penunjang keindahan alam. Perda ini merupakan salah satu Perda yang mencegah alih fungsi lahan, termasuk di dalamnya alih fungsi lahan sawah. Subak tidak dilibatkan 


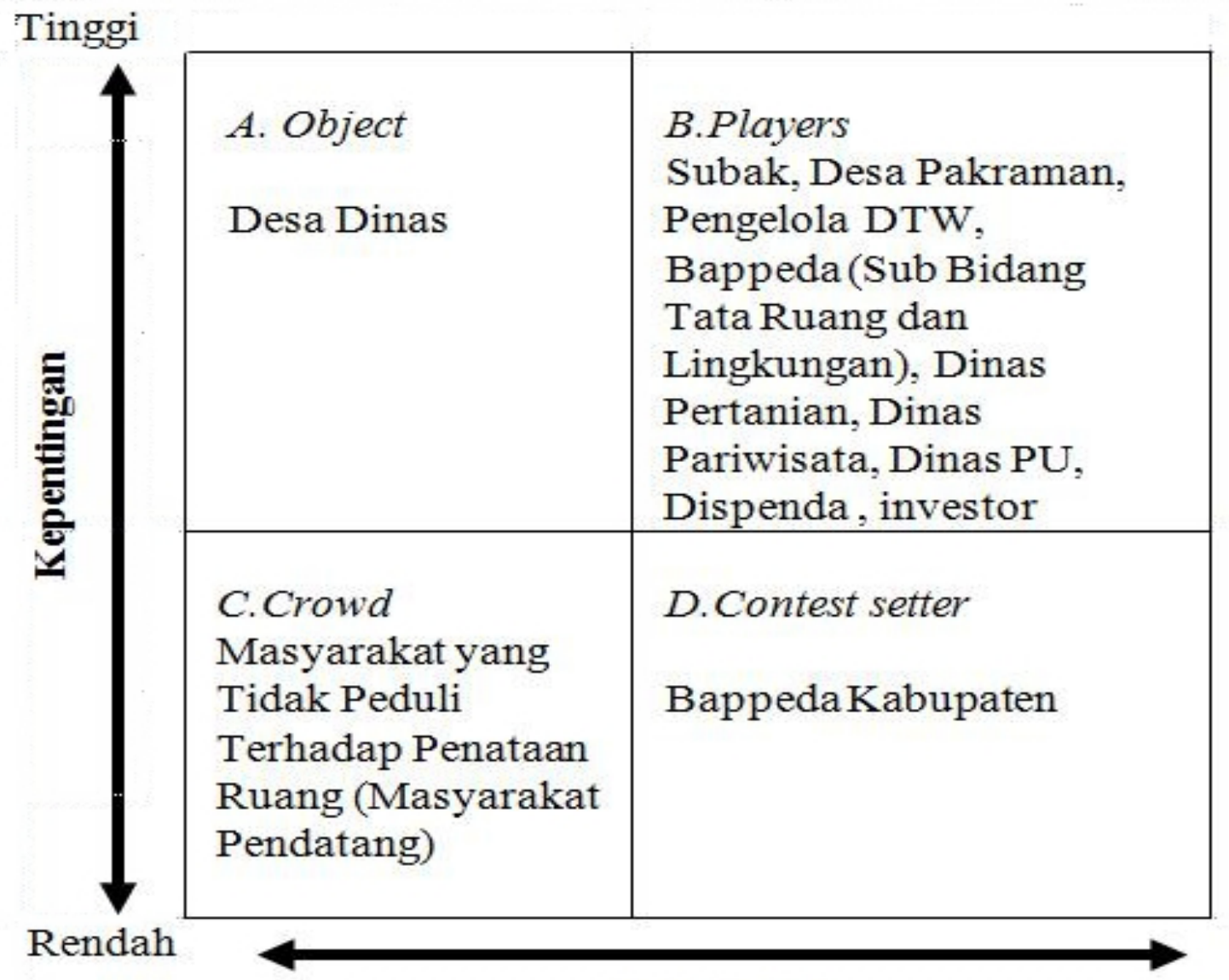

\section{Kekuatan}

Gambar 3. Matriks analisis stakeholders yang diharapkan dalam pengendalian konversi lahan pertanian yang berbasis kelembagaan lokal di Kabupaten Tabanan

banyak dalam penetapan Perda tersebut. Keterlibatan subak lebih difokuskan pada saat pengukuran batas wilayah subaknya.

Investor dalam penataan ruang (khususnya yang menyangkut pengembangan kawasan pariwisata) dilibatkan dalam hal perencanaan dan pelaksanaan. Peran investor lebih banyak mengarah pada penyediaan infrastruktur sarana prasarana penunjang pariwsata. Keberadaan investor ini sering menimbulkan trade off , dimana di satu sisi keterlibatannya sangat dibutuhkan pemerintah setempat sebagai penyedia fasilitas pariwisata, tetapi di sisi lain keberadaan investor justru mengakibatkan alih fungsi lahan.

Keterlibatan desa dinas di Bali umumnya dan di Tabanan khususnya sangat besar dalam tata ruang di wilayahnya. Meskipun tupoksi yang dilakukan desa dinas adalah menjalankan fungsi-fungsi administratif, keberadaan desa dinas juga menentukan keberadaan lahan sawah di desanya. Dalam pengukuran lahan di desa, desa dinas lebih banyak dilibatkan oleh Badan Pertanahan Negara (BPN).

\section{Crowd}

Masyarakat pada kotak crowd adalah mereka yang mempunyai minat kecil terhadap masalah penataan ruang, khususnya konversi lahan. Mereka ini enggan menjadi subyek dalam suatu kegiatan. Kebanyakan mereka adalah para pendatang dari luar Bali. Rasa empati terhadap tata ruang sekitar sangat jarang ada pada diri mereka karena lahan yang mereka tempati merupakah lahan sewa.

\section{Contest Setter}

Contest setter adalah mereka yang mempunyai minat kecil dan wewenang yang besar. Contest setter dalam penataan ruang diartikan sebagai perencana makro dari pembangunan, karena lingkup kerjanya yang tergolong luas.

Kondisi inilah yang menyebabkan minatnya kecil terhadap penataan ruang. Contest setter memiliki wewenang yang besar karena contest setter mempunyai wewenang untuk mengesahkan program-program dari instansi terkait, termasuk wewenang dalam prioritas pemberian anggaran. Bappeda kabupaten berperan sebagai contest setter. Bappeda merupakan lembaga teknis daerah dan berperan sebagai unsur penunjang pemerintah daerah. Tupoksi yang dijalankan lebih dominan pada perumusan kebijakan teknis perencanaan, pengkoordinasian penyusunan perencanaan pembangunan, dan pembinaan serta pelaksanaan tugas di bidang perencanaan pembangunan daerah.

Berdasarkan analisa stakeholder (melalui tupoksi) tersebut, kedudukan subak, desa pakraman, dan pengelola Daya Tarik Wisata (DTW) sebaiknya pada tingkat players. Kelembagaan lokal tersebut diharapkan berperan mulai dari perencanaan hingga evaluasi pada penataan ruang sekitarnya karena merekalah yang lebih mengetahui keberadaan dan permasalahan tata ruang di sekitarnya. Jika kondisi ini terjadi, konversi lahan sawah ke non sawah dapat diperkecil bahkan tidak terjadi di wilayah mereka. Di lain pihak, kedudukan 
desa dinas sebaiknya sebagai subject supaya posisinya sebagai "penumpang gelap" (free leader) tidak terjadi dalam transaksi jual beli lahan.

\section{Peta Konstelasi Kuasa Pengetahuan tentang Sumberdaya Lahan dan Air}

Michael dan Johan (2010) memaparkan pengetahuan sebagai kapasitas manusia untuk memahami dan menginterpretasikan baik hasil pengamatan maupun pengalaman, sehingga bisa digunakan untuk meramalkan ataupun sebagai dasar pertimbangan dalam pengambilan keputusan. Pengetahuan merupakan keluaran dari proses pembelajaran, penjelasan berdasarkan persepsi. Di dalamnya tercakup pula pemahaman dan interpretasi yang masuk akal, namun pengetahuan bukan merupakan kebenaran yang mutlak. Pengetahuan tidak mengarah ke suatu tindakan nyata. Kondisi dan hambatan karena adanya norma budaya atau kewajiban dapat mempengaruhi keputusan yang diambil. Faktor-faktor eksternal seperti kekuatan pasar, isu tentang kebijakan akan mendorong seseorang (petani) untuk memilih tindakan manajemen yang sub-optimal secara ekologi.

Berbeda dengan pengetahuan indigenous. Secara umum pengetahuan indigenous merupakan pengetahuan yang digunakan oleh masyarakat lokal untuk bertahan hidup dalam suatu lingkungan khusus (Nyong et. al 2007). Pengetahuan indigenous juga merupakan sekumpulan pengetahuan yang diciptakan oleh sekelompok masyarakat dari generasi ke generasi yang hidup menyatu dan selaras dengan alam (Satish 2007).

Pengetahuan yang dimiliki oleh kelembagaan lokal subak dan desa pakraman teridentitas sebagai pengetahuan indigenous. Subak memelihara pengetahuan lokal tentang konservasi lahan dan air. Lahan dan air merupakan satu kesatuan objek sumberdaya alam yang saling terkait. Pengetahuan ini diterapkan secara turun temurun. Para krama subak berpendapat bahwa sawah mereka adalah warisan penglingsir keluarga. Mereka merasa bersalah jika mengabaikan warisan ini apalagi menjualnya. Mereka semampunya akan mengelola lahan sawah sebaik mungkin untuk kepentingan keluarga, sekala, dan niskala. Pengetahuan lokal tersebut dideklarasikan dalam bentuk awig-awig sebagai upaya pengendalian konversi lahan sawah. Dalam awig-awig subak disebutkan bahwa:

Sape sire sane ngadol utawi numbas carik ring wewidangan subak patut: (1). Mesadok ring prajuru subak utawi Pekaseh Gede; (2). Patut nginutin sepopa-pali pemargin subak gede sane sampun memargi; (3). Yening wenten salah sinungil carik krama subak gede magentos wiguna ayahan lan pola-pali ring kahyangan mangda kasungkemin

Artinya:

Siapapun yang menjual atau membeli sawah di wilayah subak wajib: (1). Melapor kepada prajuru (pengurus) atau pekaseh (ketua) gede; (2). Wajib mematuhi aturan yang sudah disepakati subak gede yang telah berjalan; (3). Jika ada salah satu sawah krama (anggota) subak gede beralih fungsi terkait dengan kewajiban dan aturan di Khayangan (Pura atau tempat suci) agar disepakati

Dari kutipan di atas terlihat bahwa prajuru subak dan pekaseh subak gede memiliki peran penting dalam upaya penanggulangan terjadinya alih fungsi lahan di wilayah subak.
Setiap krama subak harus melakukan mekanisme pelaporan jika ingin menjual lahan sawahnya. Aturan ini juga berlaku bagi masyarakat di luar subak yang akan mengalihfungsikan lahan sawahnya menjadi lahan nonpertanian. Mekanisme ini harus berdasarkan syarat-syarat tertentu terutama dalam ayah-ayahan (kewajiban) harus tetap dijalankan seperti dalam pengadaan bangunan-bangunan subak, pelaksanaan upacara keagamaan dan kewajiban lainnya. Disamping aturan-aturan tersebut, prajuru subak juga memberikan himbauan-himbauan secara insentif kepada krama subak untuk mempertahankan lahan pertanian mereka. Akan tetapi untuk menciptakan situasi tertib hukum di masyarakat tidak hanya diperlukan aturan itu semata, sangat diperlukan penerimaan masyarakat terhadap hukum itu sendiri.

Desa pakraman yang berperan sebagai aktor yang membentengi keberlangsungan dan kelestarian subak, memandang juga lahan sebagai 'ibu pertiwi'. Desa pakraman tetap menominasikan awig-awignya sebagai pengikat warganya yang juga merupakan warga dari anggota subak itu sendiri. Ikatan ini merupakan upaya desa pakraman dalam mempertahankan lahan yang ada di wilayah desa adat.

Schlager dan Ostrom (1992) menegaskan bahwa pengelolaan air sebagai objek kesatuan lahan juga harus dibenahi melalui perspektif kelembagaan. Pengelolaan air dari perspektif kelembagaan dapat diartikan sebagai kewenangan membuat keputusan dalam pemanfaatan sumberdaya air. Pengelolaan air merupakan salah satu tipe hak atas air yang dapat bersifat kumulatif, termasuk di dalamnya berupa hak atas air (water rights). Hak atas air misalnya hak untuk akses, yaitu hak untuk masuk dalam suatu kawasan sumberdaya; hak pemanfaatan, yaitu hak untuk mamanfaatkan satuan dari sumberdaya; hak mengenyampingkan (exclusion right), yaitu hak untuk menentukan siapa yang boleh dan tidak boleh masuk kawasan dan memanfaatkan sumberdaya; dan hak transfer yaitu hak untuk menjual atau menyewakan sumberdaya. Dengan pengelolaan air yang berperspektif kelembagaan ini maka dapat membangun kembali elemen modal sosial (social capital) yang pada akhirnya dapat memperkuat prinsip "subsidiarity" atau ketangguhan lokal untuk menjaga goncangan-goncangan yang berasal dari luar.

Subak dan desa pakraman memandang air sebagai perwujudan 'DewaWisnu' yang harus dipelihara dan dikelola secara berkelanjutan. Air di mata aktor subak dan desa pakraman merupakan obyek konservasi. Air sebagai public goods (barang publik) yang kemudian mengarah pada common pool resources (sumberdaya milik bersama) dapat digunakan tetapi tidak boleh dikomersialkan. Dalam pembagian air, subak menerapkan pola one inlet and one outlet (satu pintu masuk dan satu pintu keluar). Pengetahuan lokal subak ini akhirnya terwujud dalam mekanisme sistem pembagian air yang adil untuk seluruh anggota subak.

Pemerintahan desa dinas memandang sumberdaya lahan dan air sebagai economic goods (barang ekonomi) yang mengarah pada private goods (barang privat). Desa dinas tunduk pada sistem pengetahuan modern ala UU Desa Nomor 6 Tahun 2014. Keterlibatan desa dinas sangat besar dalam tata ruang di wilayahnya. Meskipun tupoksi yang dilakukan desa dinas adalah menjalankan fungsi-fungsi administratif, keberadaan desa dinas juga menentukan keberadaan lahan sawah di desanya. Dalam pengukuran lahan di desa, desa dinas lebih banyak dilibatkan oleh Badan Pertanahan Negara (BPN), terutama dalam transaksi jual beli lahan.

Pemerintah kabupaten memelihara sistem pengetahuan manajemen pemerintahan ala demokrasi Barat termasuk dalam pengelolaan sumberdaya lahan dan air. Dominasi misi pada 
percepatan pertumbuhan justru menimbulkan penggerusan lahan pertanian. Rencana Tata Ruang Wilayah (RTRW) yang dibuat pemerintah justru mengkonversikan lahan sawah yang beririgasi teknis. Pemerintah kabupaten yang memiliki ideologi growthisme, komersialisme, utilitatianisme, dan opportunisme sangat berseberangan dengan ideologi kelembagaan lokal subak dan desa pakraman.

Konstelasi kekuatan ini serupa terjadi pada korporasi hotel dan amusement. Kolaborasi ini juga memelihara pengetahuan tentang ekonomi kapitalisme modern, utilitarian, dan opportunisme. Sumberdaya lahan dipandang sebagai barang eksklusif yang hanya mampu dikuasai oleh pemilik modal yang kuat seperti mereka. Sumberdaya air dipandang sangat rendah harkat dan martabatnya. Air sebagai barang komersial yang digunakan untuk memenuhi nafsu pengakumulasian profit. Orgasme nafsu kapitalis akan membuncah, bila air berhasil dikomersialisasikan untuk menghasilkan uang. Hotel atau vila yang ada di daerah kabupaten Tabanan telah berkorporasi dengan pihak PDAM dalam memanfaatkan sumber-sumber air di kabupaten tersebut, yang pada akhirnya justru menumbangkan keberlanjutan air irigasi bagi subak. Sistem ideologi dan pengetahuan korporasi itu 180 derajat berlawanan dengan ideologi dan sistem pengetahuan subak serta desa pakraman dengan Tri Hita Karana-nya (menjaga keseimbangan dan keselarasan antara hubungan manusia dengan Tuhan, manusia dengan manusia, manusia dengan lingkungannya).

Aktor lainnya yang juga berseberangan dengan subak dan desa pakraman adalah LSM. LSM yang oportunis berada dimanamana. Lahan dipandang sebagai sesuatu yang eksklusif yang bisa dikomersialkan. Jika terjadi kasus konflik lahan, LSM ikut tampil dalam memerankan 'malaikat penolong', namun dibalik aktingnya, LSM berperan sebagai media perantara pihak aktor yang memiliki kekuasaan yang kuat atau pihak yang memiliki modal kuat. Air di mata LSM juga merupakan komoditas yang dapat dijual demi promosi konservasi dan pemberdayaan. Kuasa pengetahuan yang dianut LSM tidak pernah konsisten, tergantung kemana 'angin bertiup'. Sekalipun ada juga LSM yang disiplin dan konsisten, kebanyakan LSM menjadi legitimator pemerintah kabupaten dan korporasi tatkala keduanya hendak 'memuaskan orgasme kuasa politik dan orgasme kuasa materialisme'nya.

\section{Bentuk dan Relasi Kuasa Pengetahuan Sumberdaya Lahan dan Air}

Relasi kuasa merupakan hubungan berdasarkan kepentingan (vested interest) antara berbagai kelompok atau entitas yang berada dalam satu entitas wilayah. Kekuasaan yang menjadi dasar realitas sosial dalam pandangan Foucault bersifat produktif dan tidak kelihatan karena ia ada di mana-mana, menyebar dan menyusup dalam setiap aspek kehidupan, serta terserap dalam ilmu pengetahuan dan praktik sosial yang untuk selanjutnya menciptakan rezim kebenaran. Pemikiran Foucault (Derek 2007) yang utama adalah penggunaan analisis diskursus untuk memahami kekuasaan yang tersembunyi di balik pengetahuan. Analisisnya terhadap kekuasaan dan pengetahuan memberikan pemahaman bahwa peran pengetahuan pembangunan telah mampu melanggengkan dominasi terhadap kaum marjinal. Ia mencontohkan bahwa pembangunan di negara dunia ketiga merupakan tempat berbagai kekuasaan dunia sekaligus adanya hubungan penting tentang berperanannya kekuasaan di negara-negara tersebut.

Foucault (1991) juga memaparkan bahwa setiap strategi yang mengabaikan berbagai bentuk power tersebut maka akan terjadi kegagalan. Untuk melipakgandakan power, harus berusaha bertahan dan melawan dengan jalan melipatgandakan resistensi dan kontra-ofensif. Localize-resistence tersebut haruslah bersifat radikal dan tanpa kompromi untuk melawan totalitas kekuasaan (daripada memakai cara revolusi massa), dengan strategi yang ditujukan untuk mengembangkan jaringan kerja perjuangan, kantong-kantong resistensi dan popular base. Yang perlu mendapatkan perhatian adalah analisis power tertentu (antar individu, kelompok, kegiatan dan lain-lain) dalam rangka mengembangkan knowledge strategies dan membawa skema baru politisi, intelektual, dan kelompok tertindas lainnya, dimana power tersebut akan digugat. Harus diakui bahwa kekuasaan itu mempesona karena setiap orang tergila-gila dengan kekuasaan dan bahkan berusaha untuk memilikinya.

Kekuasaan dalam arti tersebut lebih memiliki makna sebagai "milik" artinya kekuasaan hanya disempitkan sebagai milik pemerintah atau institusi tertentu sehingga muncul terminologi adanya perebutan dan peralihan kekuasan dalam kursi pemerintahan. Foucault sama sekali tidak memaksudkan makna kekuasaan seperti ini. Gagasan Foucault tentang kekuasaan lebih orisinal dan realistis. Kekuasaan tidak hanya menjadi milik pemimpin atau entitas yang berpengaruh dalam masyarakat tetapi kekuasaan berangkat dari kekuatan dan sumbangan pemikiran setiap subyek.

Kekuasaan bagi Foucault tidak dipahami dalam suatu hubungan kepemilikan sebagai properti, perolehan, atau hak istimewa yang dapat digenggam oleh sekelompok kecil masyarakat dan yang dapat terancam punah. Kekuasaan juga tidak dipahami beroperasi secara negatif melalui tindakan represif, koersif, dan menekan dari suatu institusi pemilik kekuasaan, termasuk negara. Kekuasaan bukan merupakan fungsi dominasi dari suatu kelas yang didasarkan pada penguasaan atas ekonomi atau manipulasi ideologi (Marx), juga bukan dimiliki berkat suatu kharisma (Weber). Kekuasaan tidak dipandang secara negatif, melainkan positif dan produktif. Kekuasaan bukan legalitas tindakan dan penghukuman dalam mengontrol yang lain, tetapi mengenai normalisasi kelakuan yang didisain dengan memanfaatkan kemampuan produktif dan reproduktif tubuh.

Konsep 'relasi kuasa' mengacu pada pengertian hubungan atau interaksi berdasarkan kekuatan yang bentuk-bentuk dan akibatnya ditentukan oleh akumulasi kekuasaan yang dimiliki kelompok atau anggota kelompok dalam berhubungan dengan kelompok lain. Dalam relasi kuasa, kelompok yang memiliki modal lebih besar cenderung memiliki kekuasaan atau daya kontrol atau daya dominasi lebih besar atas kelompok lain. Akan tetapi ini tidak mutlak, terutama kalau dilihat dari kemampuan suatu kelompok yang tampak 'lemah' sebetulnya mampu mengajukan nilai tawar (bargaining position) jika mereka memiliki kemampuan untuk menunjukkan modalmodal yang mereka miliki (Pentzold, Sebastian 2006). Persoalan sering terjadi bahwa satu kelompok tidak menyadari bahwa mereka memiliki modal yang bisa dipakai dasar untuk melakukan negosiasi. Misalnya, masyarakat yang tergabung dalam kelembagaan lokal dalam destinasi wisata memang tidak memiliki modal uang dan akses pada sumberdaya yang memerlukan kekuatan finansial, tetapi jelas mereka memiliki modal sosial dan modal budaya yang merupakan satu entitas yang tidak terpisahkan dengan daya tarik alam atau yang lainnya dari sebuah destinasi. Jika masyarakat menyadari kepemilikan seperti itu, nilai tawar mereka dalam relasi kuasa bisa lebih kuat. Kesadaran publik akan kekuasaan yang dia miliki juga ditentukan oleh situasi sosial politik. Dalam pemerintahan yang represif, otoriter, yang cenderung berpihak 
pada investor, masyarakat berada dalam posisi lemah. Mereka tidak memiliki keberanian untuk mengajukan nilai tawar dalam relasi kuasa, sebab kalau melakukan mereka akan mendapat tekanan dari pemerintah atau penguasa. Sebaliknya, dalam masyarakat yang demokratis, di mana masyarakat bebas menyampaikan aspirasinya, nilai tawar masyarakat akan lebih kuat. Mereka berani berhadapan atau melakukan negosiasi dengan pemerintah dan swasta atau investor untuk mendapatkan hak atau memenuhi kepentingannya.

Escobar(1998)memaparkanbahwa dalampengelolaan sumberdaya alam masih didominasi oleh pihak negara (pemerintah). Meski terdapat pola dominasi dengan berbagai strategi yang dilakukannya untuk mengorganisasi ruang dan pengetahuan, masyarakat marjinal tidak serta merta bersikap pasif dalam kondisi dominasi, namun juga berupaya beradaptasi dan mengupayakan trasformasi bentuk dominan untuk mencapai kepentingannya. Ia mempertegas bahwa gerakan sosial akan membawa praktik-praktik baru dalam kehidupan sosial melalui pengorganisasian ruang dan pembentukan makna-makna baru. Berdasarkan upaya transformasi sosial dan politik, kajian gerakan sosial terkait dengan persoalan sosial, politik dan ekonomi dalam ranah kultural. Escobar menempatkan analisis gerakan sosial secara lebih realistis, terutama dalam keterhubungan artikulasi kultural dan aspek politis, sosial dan ekonomi, dalam pola dominasi dan resistensi yang khas. Dalam hal inilah subjek membangun berbagai kemungkinan secara diskursif dalam konteksnya masing-masing. Selain itu, Escobar mengingatkan para peneliti gerakan sosial untuk tidak membawa asumsi-asumsi akademis dengan muatan nilai-nilai modern yang justru dapat mengaburkan realitas terbentuknya gerakan sosial, sehingga ranah kajian gerakan sosial yang lebih realistis dapat terbuka lebar.

Relasi kuasa yang dimainkan oleh aktor pemerintah masih bersifat dominan dibandingkan kelembagaan lokal subak dan desa pakraman. Perencanaan-perencanaan yang terkait dengan pengelolaan sumberdaya alam seperti lahan dan air masih ditangani langsung oleh aktor-aktor di tingkat pemerintahan tersebut. Kondisi inilah akhirnya menggelembungkan biaya yang harus dianggarkan, padahal hal tersebut sebenarnya bukan merupakan point dari skenario pembangunan. Aktor investor yang memiliki kekuatan modal dan bertahta sebagai 'raja' selalu melicinkan perencanaan-perencanaan tata ruang yang memberikan 'profit seeking' terbesar bagi dirinya. Kolaborasi antara swasta dengan pemerintah sering menggoyahkan pihak pemerintah untuk bertindak di luar konteks aturan.

Kegoyahan pemerintah inilah dapat dikategorikan sebagai kegagalan program konservasi lahan dan air. Konteks ini menggambarkan bahwa kekuasaan dipandang sebagai mekanisme dominasi yang merupakan bentuk kekuasaan terhadap yang lain dalam relasi yang mendominasi dengan yang didominasi atau yang powerful dengan powerless. Kekuasaan bukan seperti halnya bentuk kedaulatan suatu negara atau institusi hukum yang mengandaikan dominasi atau penguasaan secara eksternal terhadap individu atau kelompok. Kekuasaan harus dipahami sebagai bentuk relasi kekuatan dimana kekuasaan itu beroperasi. Kekuasaan juga dipahami sebagai sesuatu yang melanggengkan relasi kekuatan yang membentuk rantai atau sistem dari relasi atau justru yang mengisolasi mereka dari yang lain dari suatu relasi kekuatan. Oleh karena itu, kekuasaan merupakan strategi di mana relasi kekuatan adalah efeknya.

\section{Integrasi Dua Sistem Pengetahuan Menuju Dualitas Tata Kelola Sumberdaya Lahan dan Air}

Dualisme para aktor yang saling berkolaborasi (pemerintah dengan swasta/investor; subak dengan desa pakraman) dalam pengelolaan sumberdaya lahan (termasuk air) dapat dipecahkan melalui pendekatan strukturasi. Demartoto (2013) memaparkan bahwa teori strukturasi merupakan teori yang menepis dualism (pertentangan) dan mencoba mencari linkage atau pertautan setelah terjadi pertentangan tajam antara struktur fungsional dengan konstruksionisme fenomenologis. Giddens tidak puas dengan teori pandangan yang dikemukakan oleh strukturalfungsional, yang menurutnya terjebak pada pandangan naturalistik. Pandangan naturalistik mereduksi aktor dalam stuktur, kemudian sejarah dipandang secara mekanis, dan bukan suatu produk kontengensi dari aktivitas agen. Tetapi Giddens juga tidak sependapat dengan konstruksionismefenomenologis, yang baginya disebut sebagai berakhir pada imperalisme subjek. Oleh karenanya ia ingin mengakiri klaimklaim keduanya dengan cara mempertemukan kedua aliran tersebut.

Giddens (2011) memaparkan bahwa struktur tidak disamakan dengan kekangan (constraint) namun selalu mengekang (constraining) dan membebaskan (enabling). Hal ini tidak mencegah sifat-sifat struktur sistem sosial untuk melebar masuk kedalam ruang dan waktu diluar kendali aktor-aktor individu, dan tidak ada kompromi terhadap kemungkinan bahwa teoriteori sistem sosial para aktor yang dibantu ditetapkan kembali dalam aktivitas-ativitasnya bisa merealisasikan sistemsistem tersebut. Bagi Giddens, antara pelaku (agency) dan struktur (structure) adalah hubungan "dualitas". Selanjutnya, dikatakan bahwa "dualitas" selalu terjadi pada praktik sosial yang berulang dalam lintasan ruang dan waktu. Dualitas itu terletak dalam fakta, bahwa ia bisa dipandang sebagai aturan yang menjadi prinsip bagi tindakan di berbagai ruang dan waktu, sekaligus ia merupakan hasil (outcome) dan sarana perulangan tindakan kita, yang karenanya mengatasi ruang dan waktu.

Penelitian yang dilakukan oleh Pranaji dan Helena (2012) memaparkan bahwa ditinjau dari perspektif sosio-historis, pengelolaan lahan tidak berada dalam "ruang kosong". Aspek tekno-ekologis, hak-hak sosio-historis secara komunal, hak-hak atas dasar hukum nasional, kebijakan politik, dan penyelenggaraan pemerintahan secara simultan harus mengisi ruang dinamika penggunaan berbagai kewenangan dalam pengelolaan lahan. Penggantian penggunaan lahan (pangan) menjadi satu kebutuhan lain harus diganti oleh penyediaan lahan di tempat lain dalam ukuran (jumlah dan kualitas) yang sesuai. Pemerintah seharusnya tidak membiarkan jika salah satu lembaga atau perorangan secara semena-mena mengambil hak kehidupan masyarakat petani dengan dalih bahwa lahan yang diusahakan petani adalah haknya. Di satu sisi, petani tidak memiliki kewenangan atau hak atas lahan milik pihak lain untuk berusaha tani, namun di sisi lain petani memiliki hak untuk memperoleh lahan pertanian untuk memenuhi kebutuhan hidup dan keluarganya. Konflik penggunaan lahan untuk pertanian ini terjadi di semua tempat, namun umumnya posisi petani sangat lemah.

Ketidakmampuan pemerintah menjalankan undang-undang dan peraturan secara konsekuen telah mengakibatkan banyak konflik dengan pertikaian yang tidak jarang harus dibawa ke pengadilan. Bentuk-bentuk konflik yang banyak terjadi akhir-akhir ini tidak terlepas dari kepentingan politik dan ekonomi masyarakat sendiri. Contoh pemanfaatan lahan yang sering mengundang konflik di antaranya adalah lahanlahan di wilayah kehutanan, lahan pertambangan (galian tanah), dan lahan produktif dengan infrastruktur memadai di wilayah pedesaan dan sekitar perkotaan. Lembaga pemerintah harus membela kepentingan masyarakat. Lembaga ini berperan menegakkan peraturan dan ketentuan yang berlaku. Pemihakan kepada salah satu lembaga lain untuk kepentingan 
individu, kelompok, atau pihak lain hanya akan mengundang konflik baru. Para aktor yang terkait dengan pemanfaatan dan penataan lahan harus terintegrasi, berdiri di atas semua kepentingan dengan menjunjung tinggi peraturan dan ketentuan yang ada, termasuk dan lebih utama undang-undang yang berlaku.

Kepentingan para aktor di tingkat pemerintahan dan pihak swasta yang memiliki rangkulan yang sama dalam motif mengejar "keuntungan" telah membuat kelembagaan subak dan desa pakraman semakin terjepit. Kelembagaan subak dan desa pakraman yang merupakan perencana dan evaluator langsung pada pengelolaan lahan pertanian dan lahan desa adat memiliki visi yang berbeda dengan para aktor pemerintahan dan pihak swasta. Keberlanjutan lahan pertanian, keberlanjutan pangan, dan keberlanjutan eksistensi kedua kelembagaan lokal tersebut menjadi motivasi untuk bertahan hidup. Pencegahan konversi lahan lebih kuat dilakukan oleh subak dan desa pakraman, namun usaha ini sering juga mendapat kendala karena kelemahan hukum di pihak subak dan desa pakraman. Keberadaan mereka tidak didukung dengan peraturan daerah yang menjamin kelangsungan hidup para petani. Terjadilah dilema antara dua kekuatan tersebut, yaitu: (1) tujuan konversi yang menjadi misi aktor pemerintah dan swasta/investor bertolak belakang dengan tujuan konservasi yang menjadi amanat subak dengan desa pakraman; (2) kekuatan yang asimetrik terhadap lahan dari kedua kolaborasi aktor' (3) konformitas (bentuk interaksi yang didalamnya seseorang berperilaku terhadap orang lain sesuai dengan harapan kelompok, Klucharev et. al 2009) yang terbelah; (4) divergensi kepentingan ekonomi politik terhadap tanah; dan (5) tata kelola lahan yang bersifat "privat" dari aktor pemerintah daerah dengan tata kelola lahan yang "kolektif" dari subak dan desa pakraman.

Penelitian yang dilakukan oleh Turner dan Paul (2008); Pranaji dan Helena (2012), dapat disimpulkan bahwa perebutan hegemoni (politik) ekonomi umumnya diikuti oleh perekayasaan politik terhadap rezim suatu pemerintahan. Kondisi ini menjadi penyebab masalah penguasaan lahan tidak bebas dari praktek penyalahgunaan jabatan pada kelembagaan publik (politik, pemerintahan, hukum, lembaga adat, dan pengusaha). Kesenjangan antara visi ideal konstitusi dengan praktek pengelolaan sumberdaya strategis (termasuk lahan) masih sangat besar. Interaksi subak dengan kalangan pengusaha pada umumnya berjalan tidak sepadan. Subak sering dirugikan. Kasus yang paling menonjol di Kabupaten Tabanan adalah pemakaian seluruh air dari mata air Yeh Gembrong di kawasan Kecamatan Penebel, oleh pihak PDAM Kabupaten Tabanan. Mata air tersebut merupakan sumber air utama dari semua subak yang mendapatkan air irigasi dari sungai Yeh Ho. Dengan diambilnya semua air dari mata air tersebut, maka air yang mengalir di sungai Yeh Ho menjadi sangat berkurang. Roth (2014) juga memperkuat kajian dualisme tersebut, bahwa adanya pertumbuhan sektor pariwisata yang tajam justru dapat menimbulkan tekanan bagi kelembagaan subak, yaitu terjadinya arus konversi lahan pertanian. Manajemen subak yang merupakan manajemen kolektif (selalu berkoordinasi antara subak, subak gede, dan desa pakraman) tidak terpetakan dalam Rencana Pembangunan Jangka Menengah (RPJM), Rencana Pembangunan Jangka Panjang (RPJP), dan RUTR.

Demartoto (2013) mempertegas pendapat Giddens mengenai 'dualitas struktur'. Dualitas struktur merupakan dasar utama kesinambungan dalam reproduksi sosial dalam ruang dan waktu. Pada gilirannya hal ini mensyaratkan monitoring refleksif agen-agen dan sebagimana yang ada di dalam aktivitas sosial sehari-hari. Namun jangkauan pegetahuan manusia itu selalu terbatas. Arus suatu tindakan senantiasa

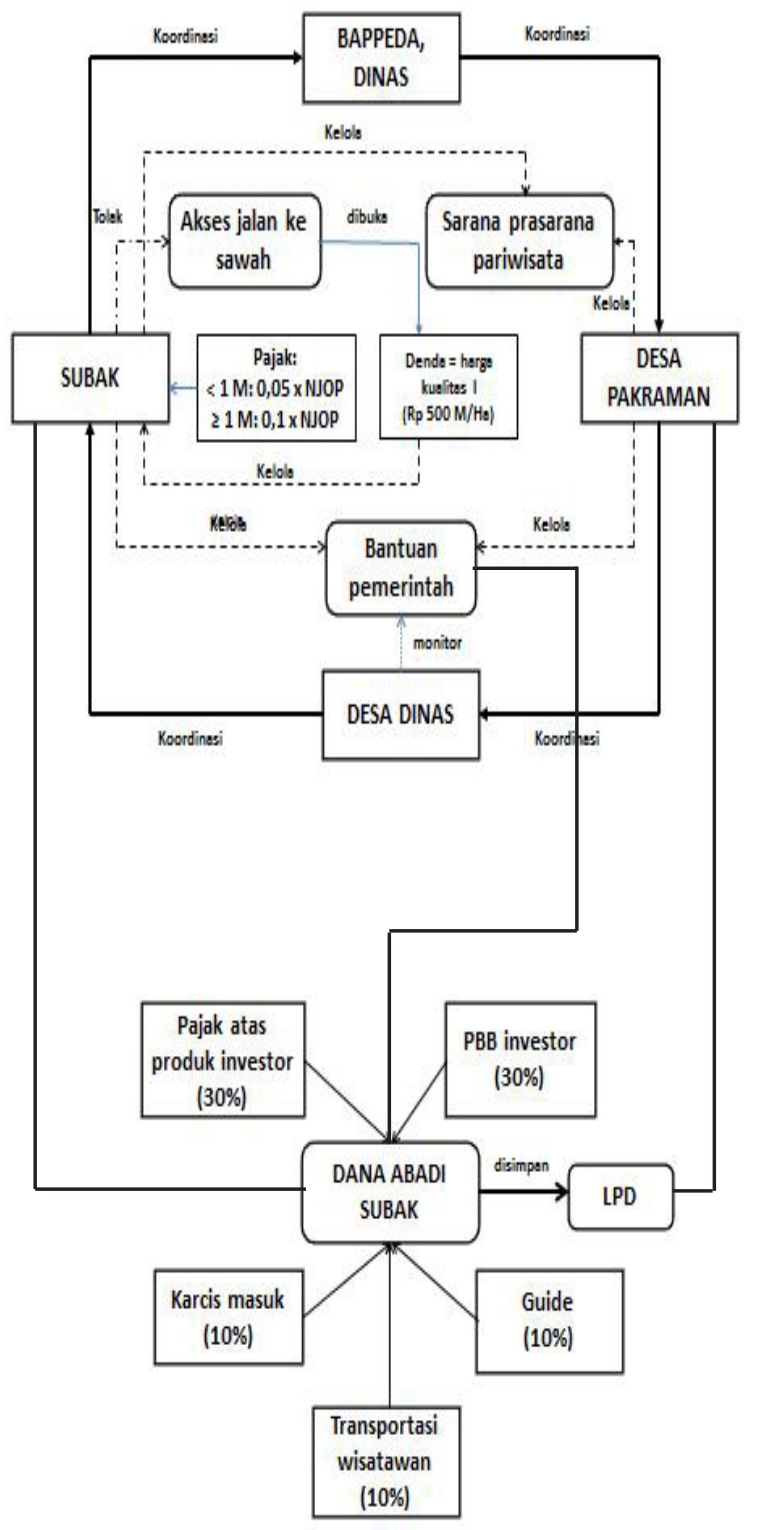

Gambar 4 Mekanisme aturan main (role game) antara aktor pemerintahan dengan aktor di tingkat kelembagaan lokal (subak dan desa pakraman)

desa dinas dan kelembagaan pemerintah lainnya. Kekuatan pemerintah yang berkolaborasi dengan pihak swasta, dan subak yang berkolaborasi dengan desa pakraman dipersatukan melalui tata kelola yang sama yang disebut sebagai "the duality of land governance" ke dalam sistem perencanaan pembangunan. Dalam hal ini, sebenarnya teori kelembagaan dimainkan secara mendalam dalam perencanaan pembangunan wilayah. Salah satu upaya penting dari perspektif sosiologi perdesaan untuk menahan laju konversi lahan pertanian sawah ke peruntukan non sawah adalah restorasi dan relegitimasi subak dalam organisasi produksi yang berbasis tanah. Keberadaan subak dikembalikan pada fungsi semula (sebagai organisasi pendistribusian air dan organisasi produksi pangan yang bersifat sosio-agraris-religius dengan diperkuat oleh aturan lokal (awig-awig) dan peraturan daerah setempat. Sumberdaya air yang dikelola subak merupakan komponen yang membentuk identitas budaya dan kekuatan pembangunan masyarakat Bali, berdasarkan filosofi Tri Hita Karana. 
Terwujudnya kawasan desa wisata memerlukan juga adanya investasi yang berlandaskan Tri Hita Karana. Setiap bentuk investasi harus berdampak positif bagi manusia yang menempati wilayah tersebut, tidak merusak lingkungan, dan tetap menjaga nilai-nilai dan hubungan transendental manusia dengan Sang Pencipta. Investasi tersebut juga harus diperkuat dengan faktor legalitas, bisnis, finansial, dan budaya. Investasi yang diwujudkan dalam perlindungan lahan pertanian (sawah) salah satu diantaranya dalam bentuk dana abadi subak (subak fund). Dana abadi merupakan kumpulan dana yang dikelola oleh lembaga (subak) untuk tujuan-tujuan sosial yang berasal dari para investor pariwisata dan bantuan pemerintah. Dana abadi dibentuk untuk penyediaan dana secara terus menerus untuk aktivitas atau tujuan tertentu. Pajak yang dikenai ke investor pariwisata dan produk-produk yang dijual investor sebaiknya 30 persen masuk ke dana abadi subak, sedangkan bantuan pemerintah sebesar Rp 200 juta untuk pengembangan kawasan desa wisata masuk 50 persen ke dana abadi subak. Sisanya dikelola oleh desa adat. Dana abadi subak dapat juga diperoleh dari biaya masuk wisatawan ke desa wisata. Biaya masuk wisatawan (karcis, sewa transportasi, dan tenaga pemandu wisata) juga dipotong 10 persen untuk masuk ke dana abadi subak. Dana abadi subak disimpan di LPD agar dapat juga memberikan dampak positif bagi pembangunan desa. Dana abadi subak yang dimanfaatkan adalah bunganya. Dengan adanya dana abadi subak, keberlanjutan subak dan keberlanjutan pertanian pangan dapat terwujud. Subak yang memiliki nilai yang luar biasa (outstanding value) mampu memainkan perannya sebagai penghasil pangan, sebagai habitat keanekaragaman hayati, sebagai kawasan konservasi sumber daya alam dan lingkungan sosial budaya, sebagai wahana pendidikan lingkungan, sebagai media konservasi tanah dan air, sebagai penghasil jasa (non-marketable value), dan sebagai manajemen ekosistem.

\section{KESIMPULAN DAN SARAN}

\section{Kesimpulan}

Kesimpulan dari hasil penelitian ini meliputi:

1. Terdapat dua kekuatan dari para aktor yang berpengaruh terhadap laju konversi lahan pertanian:

a. Aktor dari kalangan pemerintah atau kelembagaan non-adat. Kelompok ini biasanya kurang memperhatikan makna pentingnya lahan pertanian bagi ketahanan pangan. Mereka lebih berpandangan pragmatis, komersialistik, utilitarian. Artinya, tidak terlalu memperhitungkan dampak atas keputusan yang diambilnya pada keberlanjutan pangan. Tanah hanya dipandang sebagai modal yang dapat diperjualbelikan secara mudah tanpa melihat dampaknya pada kesatuan ekosistem alam.

b. Aktor dari masyarakat adat yang diwakili oleh subak dan desa pakraman. Dua kelembagaan lokal ini memiliki komitmen yang kuat terhadap ketahanan pangan. Melalui awig-awig subak dan awig-awig desa pakraman, kedua kelembagaan lokal ini akan mempertimbangkan dengan hati-hati setiap upaya warga masyarakat untuk memperjualbelikan tanahnya. Peran yang dijalankan kelembagaan lokal subak dan desa pakraman hanya menempati posisi sebagi object (kepentingan tinggi, kekuatan rendah). Peran inilah yang mengimplikasikan subak dan desa pakraman masih berada dalam ruang subordinat.
2. Konstelasi kekuatan aktor pemerintah dan swasta/investor dalam pengelolaan sumberdaya lahan dan air masih didominasi oleh pengetahuan ala demokrasi Barat yang mengagungkan ekonomi kapitalisme modern, utilitarian, dan opportunisme. Berbeda dengan subak dan desa pakraman yang masih mempertahankan pengetahuan indigenous-nya pada konservasi lahan dan air.

3. Aktor pemerintah yang berkolaborasi dengan swasta memandang kekuasaan sebagai mekanisme dominasi yang merupakan bentuk kekuasaan terhadap yang lain dalam relasi yang mendominasi dengan yang didominasi atau yang powerful dengan powerless.

4. Dualitas struktur merupakan pondasi dari dualitas tata kelola lahan (the duality of land governance). Dualitas struktur telah menjawab persoalan bagaimana agen dan struktur berintegrasi dan membangun identitasnya yang baru yang juga didukung oleh pengetahuan latar, ruang dan waktu yang memiliki karakteristiknya tertentu. Konsepsi mengenai legitimasi sangat patut untuk dicampurkan dalam bersatunya agen dan struktur yang membangun identitasnya yang baru.

\section{Saran}

Saran kebijakan yang dapat diajukan adalah:

1. Tata kelola lahan (termasuk air) membutuhkan aktoraktor (pemerintah, swasta, subak dan desa pakraman) yang berposisi sama (tidak ada dominasi kekuasaan) dan pro terhadap konservasi serta keberadaan para actor-aktor tersebut diperkuat melalui Peraturan Daerah.

2. Peraturan daerah tentang pengelolaan sumberdaya lahan dan air yang dibuat pemerintah dan awig-awig tertulis dalam subak, disarankan semakin ketat mengatur transaksi jual beli lahan pertanian agar alih fungsi lahan dapat dieliminir sekecil mungkin.

3. Perlu dibuat Perda mengenai dana abadi subak supaya kedudukan subak sebagai pengelola dana abadi subak semakin kuat dan dapat memberikan peluang kerjasama horizontal dengan beberapa desa pakraman sehamparan.

4. Pengendalian rasional dengan menetapkan sanksi disinsentif bagi semua pihak yang berusaha mengkonversi lahan dari peruntukan pertanian kepada peruntukan non-pertanian, layak dijalankan. Jikalaupun alih fungsi lahan pertanian yang ditujukan untuk pembangunan fasilitas sarana dan prasarana pembangunan umum harus terjadi (misalnya untuk pembangunan jalan raya), maka pemerintah setempat harus memberikan ganti rugi bagi petani yang terkena dampak alih fungsi lahan tersebut. Sanksi disinsentif, memberikan pertimbangan rasional untuk berpikir lebih mendalam lagi tentang dampak negatif konversi lahan pada ketahanan pangan, misalnya dengan mengganti rugi lahan sawah yang terkonversi dengan menetapkan denda bagi investor pelaku konversi lahan pertanian sebesar Rp 500 milyar/hektar (disamakan dengan rata-rata harga tanah kelas I di kabupaten Tabanan).

5. Para petani yang melestarikan sawah sepantasnya mendapatkan insentif berupa pengurangan pajak tanah (lahan sawah), hasil panen petani diwajibkan dibeli oleh pihak pemilik cottages, hotel, restoran dan pemerintah daerah, pemberian subsidi saprodi, pemberian kredit pertanian, atau dengan memberikan pengganti lahan 
dengan lahan lain yang produktif sehingga masih bisa dilakukan aktivitas pertanian. Dengan adanya dukungan insentif tersebut, selain ketahanan pangan terpelihara, karena tanah pertanian tidak terkonversi, maka secara bersamaan keseluruhan ekosistem dan stakeholder di lokasi setempat mengkonservasi (melestarikan) persawahan yang secara berantai memberikan dampak positif bagi daya tarik wisata.

6. Subak dan desa pakraman harus diperhitungkan dalam setiap pengambilan keputusan dari setiap kebijakan pemerintah. Sudah saatnya, prinsip-prinsip subak diapresiasi semakin dalam pada setiap peraturan daerah terutama yang terkait dengan pengelolaan sumberdaya alam.

\section{DAFTAR PUSTAKA}

Barker C. 2011. Ketika Nurani Ikut Berbisnis. Jakarta: PT Elex Media Komputindo.

Bryson JM. 2003. What To Do When Stakeholders Matter: A Guide to Stakeholder Identification and Analysis Techniques. A paper presented at the London School of Economics and Political Science.

Demartoto A. 2013. Teori Strukturasi dari Anthony Giddens. BPFE, UGM, Yogyakarta.

Derek H. 2007. Discourse, Knowledge, Materiality, History: Foucault and Discourse Analysis. Part of the Series Critical Theory and Practice in Psychology and the Human Science, pp. 100-137.

[Disbud] Dinas Kebudayaan Propinsi Bali. 2005. Peraturan Daerah Nomor 3 Tahun 2001 tentang Desa Adat. Bali (ID): Disbud.

Escobar A. 1998. "Whose Knowledge, Whose Nature? Biodiversity, Conservation, and the Political Ecology of Social Movement", Journal of Political Ecology, Vol. 5 , pp.53-82.

Foucault M. 1991. “Governmentality.” Dalam The Foucault Effect: Studies in Governmentality, disunting oleh G. Burchell, C. Gordon, dan P. Miller, 87-104. Chicago: The University of Chicago Press.

Forsyth T. 2003. Critical Political Ecology: The Politics of Environmental Science. London: Routledge.

Forsyth T, Sikor. 2013. "Forests, Development and the Globalization of Justice." The Geographical Journal 179 (2): 114-121.

Giddens, Mitchell D; Richard P. Appelbaum; Deborah C; (Author). 2011. Introduction to Sociology. Eight Edition. Publisher: W. W. Norton \& Company.

Klucharev V, Kaisa H, Mark R, Ale S, Guillen F. 2009. Reinforcement Learning Signal Predicts Social Conformity. Neuron. 61(1):140-151.

Li Yuheng, Yurui L, Hans W,Yansui L. 2015. Urban-Rural Transfor- mation in Relation to Cultivated Land Conversion in China: Implications for Optimizing Land Use and Balanced Regional Development. Land Use Policy, Vol.47, April 2015, pp.218-224.

Michael Y, Johan M. 2010. Three Educational Sceanrio for the Future: Lessons from the Sociology of Knowledge. European Journal of Education. Vol.45, March 2010, pp.11-27.

Newburn, D, Sarah R, Peter B, and Adina M. 2006. Economics and Land-Use Change in Prioritizing Private Land Conservation. Conservation Biology Journal, Vol. 18, February 2006, pp. 65-75.

Nurliani, Ida Rosada. 2016. Rice Field Conversion and Its Impact on Food Availability. Agriculture and Agricultural Science Procedia, Vol. 9, pp.40-46.

Nyong A, Adesina F, Osman B. 2007. The Value of Indigenous Knowledge in Climate Change Mitigation and Adaptation Strategies in the African Sahel. Mitigation and Adaptation Strategies for Global Change, Vol.12, June 2007, Issue 5, pp.787-797.

Pasandaran E. 2006. Alternatif Kebijakan Pengendalian Konversi Lahan Sawah Beririgasi di Indonesia. Jurnal Litbang Pertanian, 25 (4), 2006, pp.123-129.

Pentzold C, Sebastian S. 2006. Foucault: First Steps Towards a Conceptual Framework for the Analysis of Wiki Discourses. Proceedings of the 2006 International Symposium on Wikis. ACM New York, pp. 59-68.

[Perda] Peraturan Daerah Kabupaten Tabanan Nomor 6 Tahun 2014 tentang Jalur Hijau. Dinas Pendapatan Daerah Kabupaten Tabanan, Propinsi Bali.

Phuc NQ, ACM Van Westen, Annelies Z. 2014. Agricultural Land for Urban Development: The Process of Land Conversion in Central Vietnam. Habitat International, Vol.41, pp.1-7.

Pranadji T, Helena JP.2012. Krisis Agraria dan Pemanfaatan Kewenangan dalam Pengelolaan Sumberdaya Lahan. Analisis Kebijakan Pertanian. 3(1):13-35.

Satish K. 2007. Integrating Scientific with Indigenous Knowledge: Constructing Knowledge Alliances for Land Management in India. MIS Quarteerly, June 2007, Vol.31, No.2, pp.355379.

Sihaloho M, Arya HD, Said R. 2007. Konversi Lahan Pertanian dan Perubahan Struktur Agraria. Studi Kasus di Kelurahan Mulyaharaja, Kecamatan Bogor Selatan, Kota Bogor, Jawa Barat. Sodality: Jurnal Transdisiplin Sosiologi, Komunikasi, dan Ekologi Manusia. Vol. 1, No 2, pp.:253270.

Turner BL, Paul R. 2008. Land Change Science and Political Ecology. Annual Review of Environment and Resources. 33(1):295-316.

Schlager E, Ostrom E. 1992. Property-rights regimes and natural resources: a conceptual analysis. Land Economics, 68 (3): 249-262. 